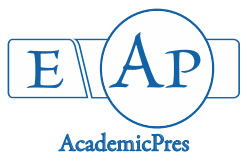

Akman H (2021)

Notulae Scientia Biologicae 13(1):10891

DOI: $10.15835 / \mathrm{nsb} 13110891$

Research Article

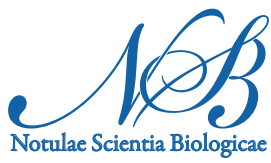

\title{
Assessment of morphological and anatomical variability in Triticum species, Aegilops species, interspecific and intergeneric hybrids
}

\author{
Hayati AKMAN
}

University of Selçuk, Department of Plant and Animal Production, 42430, Konya, Turkey; hayatiakman@selcuk.edu.tr

\begin{abstract}
Wheat species and wild relatives offer promising resources for wheat improvement and research in the current period of the genetic narrowing of modern wheat cultivars. The present study was performed to evaluate the morphological and anatomical traits of 20 diverse genotypes including Triticum and Aegilops species with intergeneric and interspecific wheat hybrids, which were compared with modern bread and durum wheat cultivars locally adapted to rainfed and irrigated conditions. The study showed that stomata density and size ranged from 55.3 to 108.6 stomata $/ \mathrm{mm}^{2}$ and 401.4 to $1296 \mu \mathrm{m}^{2}$, respectively, in the selected genotypes. Moving tetraploid to hexaploid genotypes, increased chromosome numbers yielded lower densities of large stomata in wheat species and hybrids. In this regard, the stomatal patterns of two hexaploid wheat hybrids and a wheat species including 'Agrotriticum', 'Aegilotriticum', and T. compactum, were of low density and large size stomata compared to T. durum cv. 'Kunduru 1149' with high density and small size stomata. Interestingly, the wild progenitor of the bread wheat $\mathrm{D}$ genome, Ae. tauschii, had a high density of the smallest stomata among the studied genotypes. The study further indicated that morphological parameters decreased under rainfed conditions compared to those under irrigated conditions, with levels varying among the genotypes. The rainfed flag leaf area and 1000-grain weight varied from 0.9 to $23.7 \mathrm{~cm}^{2}$ and from 7.3 to $61.9 \mathrm{~g}$, respectively under rainfed conditions, while they ranged from 1.2 to $35.7 \mathrm{~cm}^{2}$ and 11.5 to $69.9 \mathrm{~g}$ under irrigated conditions. The flag leaf area had a significant and strong association with 1000-grain weight under rainfed $\left(\mathrm{r}^{2}=0.79\right)$ and irrigated $\left(\mathrm{r}^{2}=0.77\right)$ conditions. T. turanicum and T. polonicum were characterized by the significantly highest 1000-grain weight in both rainfed and irrigated conditions. This study suggests that these wheat species with high 1000-grain weight might have promising alleles to be transferred into durum wheat to increase grain yield.
\end{abstract}

Keywords: genotypic variability; morphology; stomatal patterns; wheat species; wheat wild relatives

\section{Introduction}

Wheat is a staple source of nutrients for about $40 \%$ of the population worldwide (Giraldo et al., 2019). In the wheat evolution process, wild tetraploid wheat, Triticum dicoccoides, was produced from hybridization between diploid wild wheat Triticum urartu (genome AA) and most likely Aegilops speltoides (genome BB) (Huang et al., 2002; Peng et al., 2011). Cultivated emmer wheat (T. dicoccum) was formed by plant selection of wild emmer and then evolved into the free-threshing ears of T. turgidum, T. polonicum, T. turanicum, and T. carthlicum by natural mutation (Peng et al., 2011). Modern hexaploid bread wheat evolved through

Received: 28 Jan 2021. Received in revised form: 15 Feb 2021. Accepted: 17 Feb 2021. Published online: 18 Feb 2021.

From Volume 13, Issue 1, 2021, Notulae Scientia Biologicae journal will use article numbers in place of the traditional method of continuous pagination through the volume. 
polyploidization between T. turgidum ssp. durum (genome AABB) and Aegilops tauschii (genome DD) 10.000 years ago (Feldman et al., 1995).

Ancient wheat species, landraces, wheat wild relatives, and wheat hybrids offer biotic and abiotic stress tolerance, high biochemical and micronutrient contents, and quality in the improvement of new cultivars (Mathre et al., 1985; Cakmak et al., 2010; Arzani and Ashraf, 2017; Li et al., 2018; Ullah et al., 2018; Kishii, 2019). Wild wheat relatives and different wheat species have also been used as donors of drought tolerance in water deficit conditions (Peng et al., 2013; Ikanović et al., 2014; Suneja et al., 2019). Particularly in rainfed farming, drought can lead to severe losses (Tigkas and Tsakiris, 2015). Water deficit may affect agriculture through limiting plant productivity by inducing stomatal closure and thereby reducing photosynthesis and growth (Németh et al., 2002; Bibi et al., 2012). Photosynthesis occurring in tissues through gas exchange has been described to be closely linked with stomata density and size (Chandra and Das, 2000; Buckley, 2005; Zwieniecki et al., 2016). These characteristics of stomata on the upper and lower sides of the leaf considerably alter the gas exchange rate between inner and outer layers (Kardiman and Ræbild, 2018). Low density and large stomata could guarantee a proper photosynthetic rate and low stomatal conductance, implying that they would beneficially contribute to plants under conditions of increased $\mathrm{CO}_{2}$ and decreased water availability in the future (Yin et al., 2020). Also, in rice, stomata size has been proved to be related to grain yield, suggesting utilization possibilities for the improvement of yield in breeding programs (Limochi and Eskandari, 2013). Understanding how stomatal behaviour plays a considerable role in growth of different wheat species, hybrids, and wild wheat relatives is therefore important.

Considering the use of genetic resources, the present study aimed to determine morphological and anatomical traits and their relationships in many Triticum and Aegilops species together with their hybrids.

\section{Materials and Methods}

\section{Experimental conditions}

A field study was conducted in a randomized complete block design with three replications under rainfed and irrigated conditions in 2019 at Sarayönü Vocational School, Selçuk University, Konya, Turkey. A panel of 20 genotypes comprising different wheat species, Aegilops species, landraces, modern wheat cultivars, intergeneric and interspecific wheat hybrids was selected for the study (Table 1). T. aestivum cultivars ('Karahan 99' and 'Konya 2002') and T. durum cultivars ('Kunduru 1149' and 'Meram 2002') were used as control cultivars. Each one of locally adaptive modern cultivars represented an adverse genetic background with adaptations to rainfed and irrigated conditions, respectively.

The soil taken from the field $(0-40 \mathrm{~cm})$ and used in the experiment was clay-loam with low organic matter $(1.60 \%)$ and high levels of $\mathrm{CaCO}_{3}(31.9 \%)$ and $\mathrm{Ca}(6008 \mathrm{mg} / \mathrm{kg})$. EC was $0.61 \mathrm{mmhos} / \mathrm{cm}$. Soil pH was 7.76 and no salinity problem $(0.02 \%)$ was observed. It was low in $\mathrm{P}_{2} \mathrm{O}_{5}(44.1 \mathrm{~kg} / \mathrm{ha})$ and $\mathrm{Mn}(6.17 \mathrm{mg} / \mathrm{kg})$. $\mathrm{K}_{2} \mathrm{O}(1128 \mathrm{~kg} / \mathrm{ha}), \mathrm{Zn}(0.74 \mathrm{mg} / \mathrm{kg})$, and $\mathrm{Cu}(2.4 \mathrm{mg} / \mathrm{kg})$ were found to be adequate. The soil was high in $\mathrm{Mg}$ $(591.7 \mathrm{mg} / \mathrm{kg})$ with a moderate level of $\mathrm{Fe}(3.9 \mathrm{mg} / \mathrm{kg})$.

According to the meteorological data for the growing season regarding the long-term (1928-2018) and average annual rainfall (2019), the average rainfall values in the months of March, April, May, June, and July were very close to $136.9 \mathrm{~mm}$ in the long term and $92.8 \mathrm{~mm}$ in 2019 . The relative humidity values were $53.8 \%$ and $48.2 \%$, respectively, and the average temperature values were $15.2^{\circ} \mathrm{C}$ and $17.2^{\circ} \mathrm{C}$, respectively.

\section{Field experiment and measurements}

The sowings were made in 5 - $\mathrm{cm}$ rows with 20 - $\mathrm{cm}$ spaces between rows. At sowing, DAP fertilizer $(18 \%$ $\left.\mathrm{N}, 46 \% \mathrm{P}_{2} \mathrm{O}_{5}\right)$ was top-dressed to plots at $130 \mathrm{~kg} \mathrm{ha}^{-1}$. In the tillering stage, ammonium nitrate $(33 \% \mathrm{~N})$ was applied by broadcasting. In total, $75 \mathrm{~kg} \mathrm{ha}^{-1}$ nitrogen was used under rainfed conditions and $120 \mathrm{~kg} \mathrm{ha}^{-1}$ was used under irrigated conditions. Weeds were controlled with a chemical herbicide. The plots under irrigated 
conditions were irrigated two times in the stem elongation and booting stages. Flag leaves were excised from plants (Figure 3). Six flag leaf areas (FLA) per replication were measured using ImageJ software (https://imagej.nih.gov/ij). Harvesting was performed at the stage of full grain maturity (GS 92). Morphological parameters such as plant height per main stem, number of fertile tillers per plant, spike length per main spike, and number of spikelet's per main spike were determined for 10 plants per replication. 1000grain weight $(\mathrm{TGW})$ was determined by weighing dehulled seeds $(4 \times 100)$ per replication.

Table 1. Traits of genotypes involving Triticum species, Aegilops species, and wheat hybrids used in the study

\begin{tabular}{|c|c|c|c|c|}
\hline Genotypes & $\begin{array}{c}\text { Ploidy } \\
\text { level }\end{array}$ & Inventory & Name & Origin \\
\hline \multicolumn{5}{|c|}{ Aegilops species } \\
\hline Ae. tauschii & $2 x$ & Clae 2 & 2016 & Baluchistan, Pakistan \\
\hline Ae. peregrinavar. brachyathera & $4 \times$ & PI 603247 & TA 1885 & Central, Israel \\
\hline Ae. geniculate & $4 \times$ & Clae 65 & Sando Selection 253 & Unknown \\
\hline Ae. ventricosa & $4 \times$ & PI 127000 & M10 & Unknown \\
\hline Ae. neglecta & $4 \times$ & PI 170199 & 2646 & Turkey, Edirne \\
\hline \multicolumn{5}{|c|}{ Triticum species and hybrids } \\
\hline Elytritilops ssp. & - & PI 605347 & Sando Selection 538 & USA \\
\hline Agrotriticum ssp. & $8 \times$ & PI 550713 & Calif. 6097 & California, USA \\
\hline Aegilotriticum ssp. & $6 x$ & PI 613322 & CASS97B00063S & Mexico \\
\hline T. aestivum ssp. compactum & $6 x$ & PI 114638 & Gluclub & Victoria, Australia \\
\hline T. ispahanicum var: ispahanorufum & $4 \times$ & PI 330548 & 184 & UK, England, \\
\hline T. turgidum ssp. turgidum & $4 x$ & PI 134960 & Pseudo-mirabile & Portugal \\
\hline T. turgidum ssp. carthlicum & $4 \times$ & PI 70738 & Persian wheat & Iraq \\
\hline T. turgidum ssp. turanicum & $4 \times$ & PI 67343 & Australian Pouland & Victoria, Australia \\
\hline T. turgidum ssp. polonicum & $4 \times$ & PI 56262 & Milagre & Lisboa, Portugal \\
\hline T. turgidum ssp. dicoccoides & $4 \times$ & PI 346783 & Nakhichevan & Pest, Hungary \\
\hline T. durum cv. Meram 2002 & $4 \times$ & TR & Durum wheat & Konya, Turkey \\
\hline T. durum cv. Kunduru 1149 & $4 \times$ & TR & Durum wheat & Eskişehir, Turkey \\
\hline T. durum cv. Karakılçık & $4 \times$ & TR & Landrace & Turkey \\
\hline T. aestivum cv. Konya 2002 & $6 x$ & TR & Common wheat & Konya, Turkey \\
\hline T. aestivum cv. Karahan 99 & $6 x$ & TR & Common wheat & Konya, Turkey \\
\hline
\end{tabular}

Elytritilops ssp. is a hybridization among Elymus $\times$ Triticum $\times$ Aegilops; Aegilotriticum ssp. from a hybridization

between Triticum $\times$ Aegilops; 'Agrotriticum ssp. from a hybridization between Agropyron $\times$ Triticum

\section{Stomatal anatomy analysis}

Microscopic slides pasted with a layer of super glue were pressed on the adaxial side of a fully expanded flag leaf selected from plants grown under irrigated condition in the pre-anthesis growth stage. Approximately 60 seconds later, the slides were taken off from the leaves and the epidermal tissues were peeled off from the leaf and attached on the slides. In total, three replicates were performed in each treatment. Stomata were imaged using Nikon Eclipse E400 light microscope equipped with DS-5M digital camera head and DS-L1 camera control unit (Nikon, Japan). The microscopic area was $0.8 \mathrm{~mm}^{2}$ using a microscope resolution of $1280 \times 960$ pixel (96 dpi). Image analysis was performed using ImageJ software (https://imagej.nih.gov/ij). Twenty-four stomata widths and lengths per replicate were measured for the stomatal size (area) ([stoma width $\times$ stomata length $\times \pi] / 4$ ). Stomatal density was calculated as number of stomata in six microscopic fields per replicate (Cortan et al., 2017) (Figure 1). 

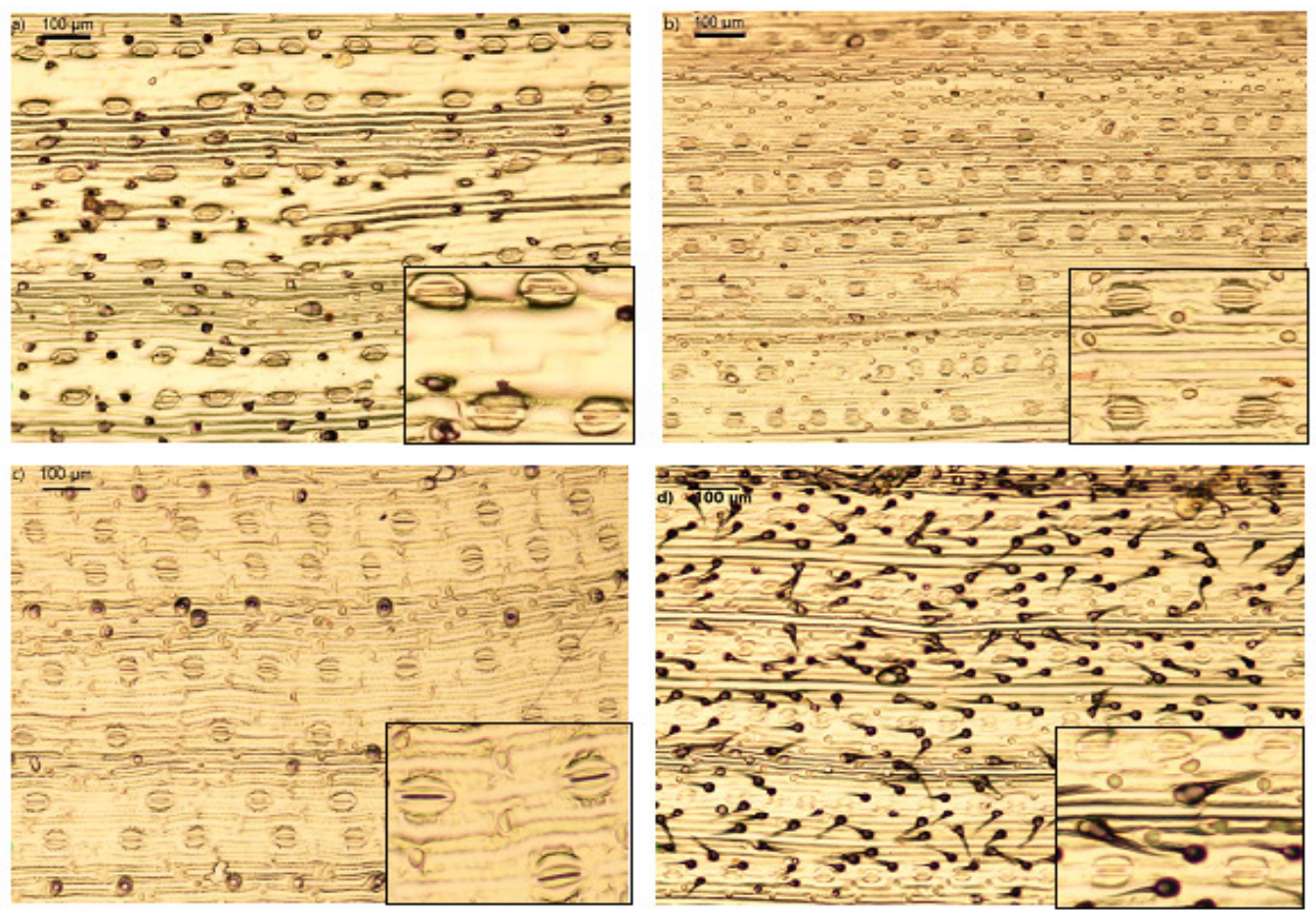

Figure 1. Stomatal diversity in wheat species and hybrids

Scale bar is $100 \mu \mathrm{m}$. The images are captured from the adaxial epidermal layers after imprinting of flag leaf tissues. Figure $1 \mathrm{a}$ is a representative of the fewest stomata in 'Agrotriticum' among the studied genotypes, figure $1 \mathrm{~b}$ is a representative of the highest density of the smallest stomata in T. durum cv. 'Kunduru 1149'. Figure 1c indicates the largest size of stomata in 'Aegilotriticum' among the genotypes. Figure $1 \mathrm{~d}$ shows stomata and typical more trichomes on epidermis of leaf in T. carthlicum. Black lined boxes are the zoomed part of the leaves showing stomatal features.

\section{Statistical analysis}

The morphological and anatomical results were evaluated by analysis of variance (general linear model procedure) and one-way Tukey's pairwise comparison test using Minitab Version 16 (Minitab Inc., State College, PA, USA). Regression analyses were performed in Microsoft Excel (Excel version in Microsoft Office 2016 for Windows) for significantly correlated traits.

\section{Results}

In this study, significant variations were observed within and between genotypes in terms of values for morphological and anatomical traits of Triticum and Aegilops species and their hybrids $(\mathrm{P}<0.0001)$.

\section{Stomatal anatomy}

Stomata exhibited a diverse range of length, width, size, and density across different wheat and Aegilops species with hybrids. Stomata length ranged from 28 to $51.6 \mu \mathrm{m}$, stomata width from 18.3 to $32 \mu \mathrm{m}$, stomata size from 401.4 to $1296 \mu \mathrm{m}^{2}$, and stomata density from 55.3 to $108.6 \mathrm{stomata} / \mathrm{mm}^{2}$ (Figure 2). 

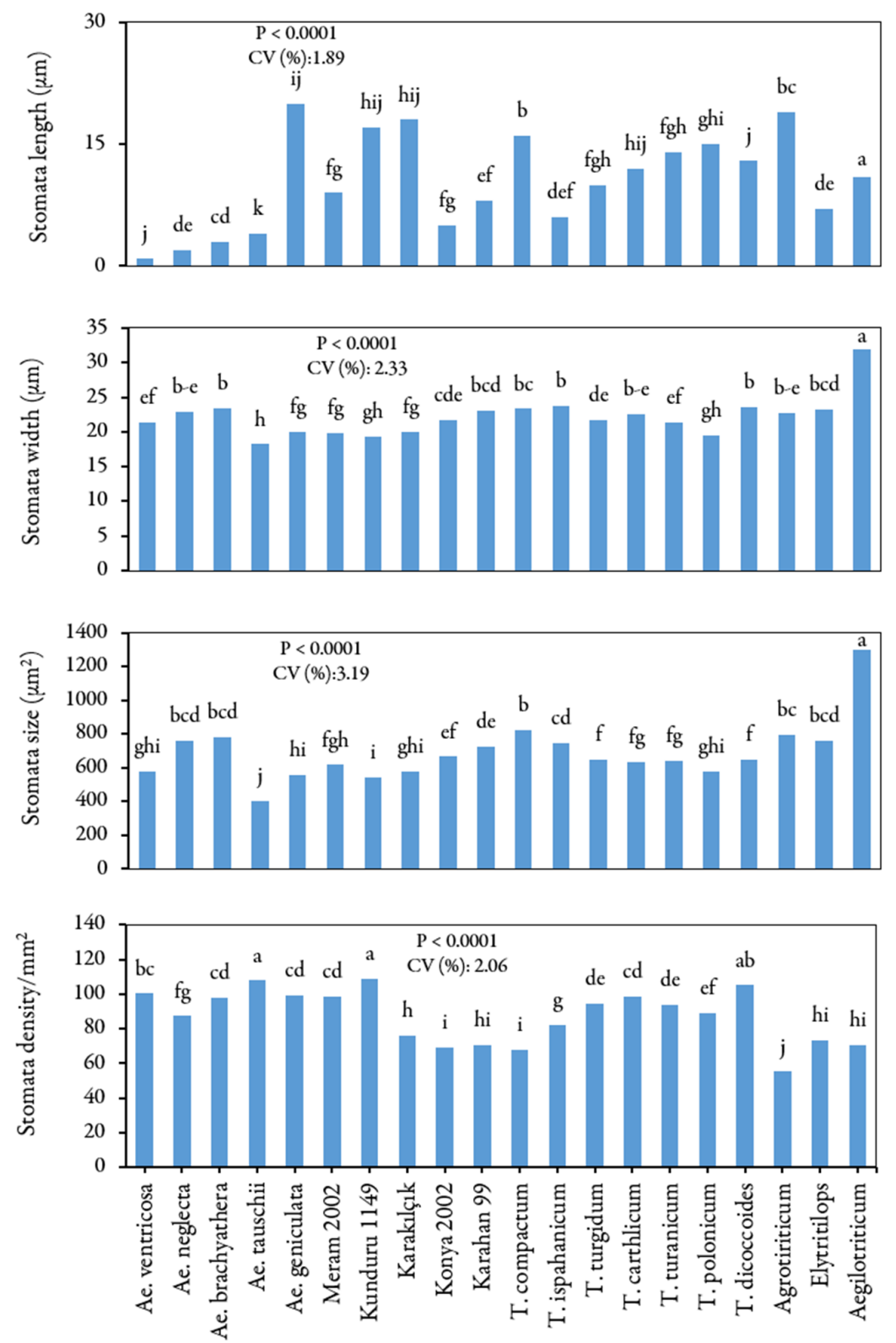

Figure 2. Stomatal length, width, size, and density of the studied genotypes

In the study, the hexaploid and tetraploid genotypes were discriminated precisely in terms of stomata density. The maximum stomatal length and width were observed in the 'Aegilotriticum' in wheat species and hybrids. Conversely, T. dicoccoides and T. durum cv. 'Kunduru 1149' had the lowest stomatal length and width, respectively. In general, the hexaploid wheat genotypes and hybrids possessed a higher stomata size compared to tetraploid wheat genotypes. In Aegilops species, Ae. tauschii, a unique genitor of bread wheat, indicated the lowest stomatal length and width (Figure 2). However, the highest values were obtained from $A e$. brachyathera. 
Table 2. Morphological traits of wheat species, Aegilops species, and wheat hybrids under rainfed conditions

\begin{tabular}{|c|c|c|c|c|c|c|}
\hline & $\begin{array}{c}\text { Plant height } \\
(\mathrm{cm})\end{array}$ & $\begin{array}{l}\text { Spike length } \\
(\mathrm{cm})\end{array}$ & $\begin{array}{c}\text { Spikelet } \\
\text { number/spike }\end{array}$ & $\begin{array}{c}\text { Tiller } \\
\text { number/plant }\end{array}$ & $\begin{array}{l}\text { Flag leaf } \\
\text { area }\left(\mathrm{cm}^{2}\right)\end{array}$ & $\begin{array}{l}\text { 1000- } \\
\text { grain } \\
\text { weight } \\
(\mathrm{g})\end{array}$ \\
\hline Ae. ventricosa & $28.1^{\mathrm{g}}$ & $9.3^{\mathrm{b}-\mathrm{e}}$ & $8.6^{\mathrm{g}}$ & $25.0^{\mathrm{bc}}$ & $2.4^{j}$ & $11.1^{\text {gh }}$ \\
\hline Ae. neglecta & $26.0^{\mathrm{g}}$ & $4.1^{\mathrm{ij}}$ & $5.3^{\mathrm{g}-\mathrm{h}}$ & $32.7^{\mathrm{ab}}$ & $1.1^{\mathrm{j}}$ & $11.7^{\text {gh }}$ \\
\hline Ae. brachyathera & $23.8^{g}$ & $5.1^{g-j}$ & $6.1^{\mathrm{g}-\mathrm{h}}$ & $21.3^{\mathrm{b}-\mathrm{e}}$ & $0.9^{j}$ & $12.4^{\mathrm{gh}}$ \\
\hline Ae. tauschii & $24.9^{g}$ & $6.7^{\mathrm{fgh}}$ & $7.9^{\mathrm{g}-\mathrm{h}}$ & $21.2^{\mathrm{b}-\mathrm{e}}$ & $1.6^{j}$ & $7.3^{\mathrm{h}}$ \\
\hline Ae. geniculata & $22.6^{\mathrm{g}}$ & $3.5^{j}$ & $3.9^{\mathrm{h}}$ & $42.3^{a}$ & $1.2^{\mathrm{j}}$ & $14.8^{g}$ \\
\hline Meram 2002 & $67.7^{\mathrm{def}}$ & $10.1^{\mathrm{abc}}$ & $19.5^{\mathrm{abc}}$ & $12.2^{\mathrm{c}-\mathrm{f}}$ & $10.9^{\text {fgh }}$ & $43.3^{c}$ \\
\hline Kunduru 1149 & $82.2^{\mathrm{abc}}$ & $6.6^{\text {gh }}$ & $16.0^{\mathrm{b}-\mathrm{f}}$ & $7.0^{\text {ef }}$ & $10.6^{\text {fgh }}$ & $43.8^{c}$ \\
\hline Karakılçık & $64.0^{\text {def }}$ & $6.2^{\text {ghi }}$ & $13.9^{\mathrm{ef}}$ & $5.2^{f}$ & $18.8^{\mathrm{bc}}$ & $43.4^{c}$ \\
\hline Konya 2002 & $65.0^{\text {def }}$ & $11.1^{\mathrm{abc}}$ & $21.2^{\mathrm{a}}$ & $6.2^{\mathrm{f}}$ & $13.0^{\mathrm{ef}}$ & $42^{c}$ \\
\hline Karahan 99 & $59.4^{\mathrm{ef}}$ & $10.2^{\mathrm{abc}}$ & $15.5^{\mathrm{c}-\mathrm{f}}$ & $9.7^{\text {def }}$ & $15.3^{\mathrm{de}}$ & $34.2^{\mathrm{d}}$ \\
\hline T. compactum & $59.1^{\text {ef }}$ & $4.5^{\text {hij }}$ & $15.8^{\mathrm{b}-\mathrm{f}}$ & $9.9^{\text {def }}$ & $15.2^{\mathrm{de}}$ & $32.5^{d}$ \\
\hline T. ispahanicum & $75.6^{\mathrm{bcd}}$ & $9.5^{\mathrm{bcd}}$ & $18.0^{\mathrm{a}-\mathrm{d}}$ & $22.2^{\mathrm{bcd}}$ & $8.0^{\text {hi }}$ & $40.4^{\mathrm{c}}$ \\
\hline T. turgidum & $91.8^{\mathrm{a}}$ & $11.4^{\mathrm{ab}}$ & $19.9^{\mathrm{ab}}$ & $6.3^{\mathrm{f}}$ & $17.4^{\mathrm{cd}}$ & $42.6^{c}$ \\
\hline T. carthlicum & $72.4^{\mathrm{b}-\mathrm{e}}$ & $9.0^{\mathrm{c}-\mathrm{f}}$ & $18.2^{\mathrm{a}-\mathrm{d}}$ & $9.6^{\text {def }}$ & $8.5^{\text {ghi }}$ & $31.7^{\mathrm{de}}$ \\
\hline T.turanicum & $84.8^{\mathrm{ab}}$ & $11.1^{\mathrm{abc}}$ & $15.3^{\mathrm{def}}$ & $7.2^{\mathrm{ef}}$ & $21.9^{\mathrm{ab}}$ & $61.9^{a}$ \\
\hline T.polonicum & $75.6^{\mathrm{bcd}}$ & $7.3^{\mathrm{d}-\mathrm{g}}$ & $17.3^{\mathrm{a}-\mathrm{f}}$ & $6.3^{\mathrm{f}}$ & $23.7^{\mathrm{a}}$ & $52.6^{b}$ \\
\hline T. dicoccoides & $77.2^{\mathrm{bcd}}$ & $7.0^{\text {efg }}$ & $15.1^{\mathrm{def}}$ & $11.5^{\mathrm{c}-\mathrm{f}}$ & $6.4^{\mathrm{i}}$ & $26^{\mathrm{f}}$ \\
\hline Agrotiriticum & $70.5^{\text {cde }}$ & $12.1^{\mathrm{a}}$ & $13.6^{\mathrm{f}}$ & $11.3^{\mathrm{c}-\mathrm{f}}$ & $8.0^{\text {hi }}$ & $24.5^{f}$ \\
\hline Elytritilops & $76.5^{\mathrm{bcd}}$ & $11.9^{a}$ & $14.8^{\mathrm{def}}$ & $10.1^{\mathrm{def}}$ & $13.5^{\mathrm{ef}}$ & $29.1^{f}$ \\
\hline Aegilotriticum & $54.5^{f}$ & $10.1^{\mathrm{abc}}$ & $14.8^{\text {def }}$ & $8.7^{\text {def }}$ & $11.5^{\mathrm{fg}}$ & $30.4^{\mathrm{de}}$ \\
\hline Mean & 60.1 & 8.3 & 14.0 & 14.3 & 10.5 & 31.8 \\
\hline $\mathrm{P}<$ & 0.0001 & 0.0001 & 0.0001 & 0.0001 & 0.0001 & 0.0001 \\
\hline CV (\%) & 7.7 & 9.0 & 9.5 & 33.2 & 10.6 & 6.2 \\
\hline
\end{tabular}

\section{Morphological parameters}

Significant variations in each parameter were observed among genotypes in both growth conditions. Plant height under rainfed and irrigated conditions ranged from 22.6 to $91.8 \mathrm{~cm}$ and 26.3 to $95.8 \mathrm{~cm}$, respectively (Tables 2 and 3 ) and was generally greater in plants in the irrigated group than the rainfed group. Aegilops species had shorter plant height than wheat species and hybrids. The spike length ranged from 3.5 to $12.1 \mathrm{~cm}$ under rainfed condition and from 3.6 to $12.6 \mathrm{~cm}$ under irrigated condition (Tables 2 and 3). The average values in both conditions were relatively close for spike length and spikelet number, as well.

Significant variations in tiller number were also observed among genotypes in both growth conditions. The tiller number varied from 5.2 and 42.3 under rainfed condition and 7.4 and 33.7 under irrigated condition (Tables 2 and 3). Aegilopsspecies and T. ispahanicum showed higher tillering capacity in both conditions than other wheat species and hybrids. The FLA ranged from 0.9 to $23.7 \mathrm{~cm}^{2}$ under rainfed conditions and 1.2 to $35.7 \mathrm{~cm}^{2}$ under irrigated conditions (Tables 2 and 3). There was a significant and strong relationship between FLA and TGW in rainfed $\left(\mathrm{r}^{2}=0.79\right)$ and irrigated $\left(\mathrm{r}^{2}=0.77\right)$ conditions (Figure 4).

The FLA under rainfed conditions was lower than that under irrigated conditions. Similarly, TGW values were reduced under rainfed conditions compared to irrigated conditions. The TGW varied widely among genotypes, ranging from 7.3 to $61.9 \mathrm{~g}$ under rainfed conditions and from 11.5 to $69.9 \mathrm{~g}$ under irrigated 
conditions (Tables 2 and 3). It was further observed that Aegilops species had lower TGWs than Triticum species and hybrids.

Table 3. Morphological traits of wheat species, Aegilops species, and wheat hybrids under irrigated conditions

\begin{tabular}{|c|c|c|c|c|c|c|}
\hline Genotype & $\begin{array}{c}\text { Plant height } \\
(\mathrm{cm})\end{array}$ & $\begin{array}{c}\text { Spike } \\
\text { length }(\mathrm{cm})\end{array}$ & $\begin{array}{c}\text { Spikelet } \\
\text { number/spike }\end{array}$ & $\begin{array}{c}\text { Tiller } \\
\text { number/plant }\end{array}$ & $\begin{array}{c}\text { Flag leaf } \\
\text { area }\left(\mathrm{cm}^{2}\right)\end{array}$ & $\begin{array}{l}\text { 1000-grain } \\
\text { weight }(\mathrm{g})\end{array}$ \\
\hline Ae. ventricosa & $30.0^{\mathrm{g}}$ & $9.8^{\mathrm{c}-\mathrm{f}}$ & $8.0^{\mathrm{de}}$ & $27.8^{\mathrm{bc}}$ & $3.3^{\mathrm{g}}$ & $11.5^{j}$ \\
\hline Ae. neglecta & $29.8^{g}$ & $4.2^{\mathrm{ij}}$ & $5.2^{\mathrm{de}}$ & $26.6^{\mathrm{bcd}}$ & $1.2^{\mathrm{g}}$ & $15.7^{\mathrm{j}}$ \\
\hline Ae. brachyathera & $27.7^{\mathrm{g}}$ & $5.7^{h-i}$ & $4.7^{\mathrm{de}}$ & $29.3^{b c}$ & $1.7^{\mathrm{g}}$ & $19.8^{\mathrm{ij}}$ \\
\hline Ae. tauschii & $30.2^{\mathrm{g}}$ & $5.4^{\text {hij }}$ & $5.4^{\mathrm{de}}$ & $25.5^{\text {cde }}$ & $2.0^{\mathrm{g}}$ & $15.9^{j}$ \\
\hline Ae. geniculata & $26.3^{g}$ & $3.6^{j}$ & $3.5^{\mathrm{e}}$ & $33.7^{\mathrm{ab}}$ & $1.9^{\mathrm{g}}$ & $17.7^{\mathrm{ij}}$ \\
\hline Meram 2002 & $68.5^{\text {def }}$ & $9.2^{\mathrm{def}}$ & $18.3^{\mathrm{ab}}$ & $11.3^{\text {gh }}$ & $21.4^{\mathrm{bcd}}$ & $46.7^{\mathrm{cd}}$ \\
\hline Kunduru 1149 & $86.4^{\mathrm{abc}}$ & $6.7^{\text {gh }}$ & $15.7^{\mathrm{ab}}$ & $11.8^{\mathrm{fgh}}$ & $19.0^{\mathrm{c}-\mathrm{f}}$ & $46.3^{\mathrm{cd}}$ \\
\hline Karakılçık & $66.6^{\mathrm{ef}}$ & $5.9^{h i}$ & $9.6^{\mathrm{cd}}$ & $9.3^{\mathrm{h}}$ & $21.0^{\text {cde }}$ & $47.2^{c}$ \\
\hline 'Konya 2002' & $65.0^{f}$ & $11.7^{\mathrm{ab}}$ & $20.3^{a}$ & $8.5^{\mathrm{h}}$ & $22.1^{\mathrm{bc}}$ & $42.5^{\mathrm{cde}}$ \\
\hline 'Karahan 99' & $74.1^{\mathrm{c}-\mathrm{f}}$ & $10.7^{\mathrm{bcd}}$ & $17.2^{\mathrm{ab}}$ & $17.5^{\mathrm{fg}}$ & $19.3^{\mathrm{c}-\mathrm{f}}$ & $42.4^{\text {cde }}$ \\
\hline T. compactum & $63.5^{f}$ & $4.5^{i j}$ & $15.9^{\mathrm{ab}}$ & $19.2^{\mathrm{def}}$ & $19.5^{\mathrm{c}-\mathrm{f}}$ & $33.8^{\mathrm{fg}}$ \\
\hline T. ispahanicum & $95.8^{\mathrm{a}}$ & $10.2^{\text {b-e }}$ & $17.9^{\mathrm{ab}}$ & $37.4^{\mathrm{a}}$ & $13.4^{\mathrm{ef}}$ & $43.2^{\text {cde }}$ \\
\hline T. turgidum & $93.1^{\mathrm{ab}}$ & $11.0^{\mathrm{abc}}$ & $20.3^{a}$ & $7.5^{\mathrm{h}}$ & $20.9^{\text {cde }}$ & $47.9^{c}$ \\
\hline T. carthlicum & $82.1^{\mathrm{a}-\mathrm{d}}$ & $10.4^{\mathrm{b}-\mathrm{e}}$ & $18.9^{\mathrm{ab}}$ & $17.5^{\mathrm{fg}}$ & $15.7^{\mathrm{def}}$ & $31.2^{\text {fgh }}$ \\
\hline T. turanicum & $88.1^{\mathrm{ab}}$ & $11.1^{\mathrm{abc}}$ & $16.5^{\mathrm{ab}}$ & $11.0^{\mathrm{gh}}$ & $27.6^{\mathrm{b}}$ & $69.9^{a}$ \\
\hline T.polonicum & $81.1^{\text {bcd }}$ & $8.6^{\mathrm{ef}}$ & $16.6^{\mathrm{ab}}$ & $7.4^{\mathrm{h}}$ & $35.7^{\mathrm{a}}$ & $59.1^{b}$ \\
\hline T. dicoccoides & $89.9^{\mathrm{ab}}$ & $8.2^{\mathrm{fg}}$ & $15.1^{\mathrm{abc}}$ & $18.0^{\text {efg }}$ & $18.1^{\mathrm{c}-\mathrm{f}}$ & $24.7^{\text {hi }}$ \\
\hline Agrotiriticum & $79.4^{\mathrm{b}-\mathrm{e}}$ & $12.6^{\mathrm{a}}$ & $14.2^{\mathrm{bc}}$ & $9.3^{\mathrm{h}}$ & $19.8^{\text {cde }}$ & $28.8^{\text {gh }}$ \\
\hline Elytritilops & $85.1^{\mathrm{abc}}$ & $11.8^{\mathrm{ab}}$ & $14.3^{\mathrm{bc}}$ & $13.3^{\mathrm{fgh}}$ & $15.0^{\mathrm{ef}}$ & $36.2^{\mathrm{efg}}$ \\
\hline Aegilotriticum & $63.9^{f}$ & $9.7^{\mathrm{c}-\mathrm{f}}$ & $15.2^{\mathrm{abc}}$ & $13.1^{\mathrm{fgh}}$ & $16.6^{\mathrm{c}-\mathrm{f}}$ & $38.8^{\text {def }}$ \\
\hline Mean & 66.3 & 8.5 & 13.6 & 17.8 & 15.8 & 36.0 \\
\hline $\mathrm{P}<$ & 0.0001 & 0.0001 & 0.0001 & 0.0001 & 0.0001 & 0.0001 \\
\hline CV (\%) & 6.8 & 6.9 & 13.8 & 13.8 & 12.8 & 7.5 \\
\hline
\end{tabular}

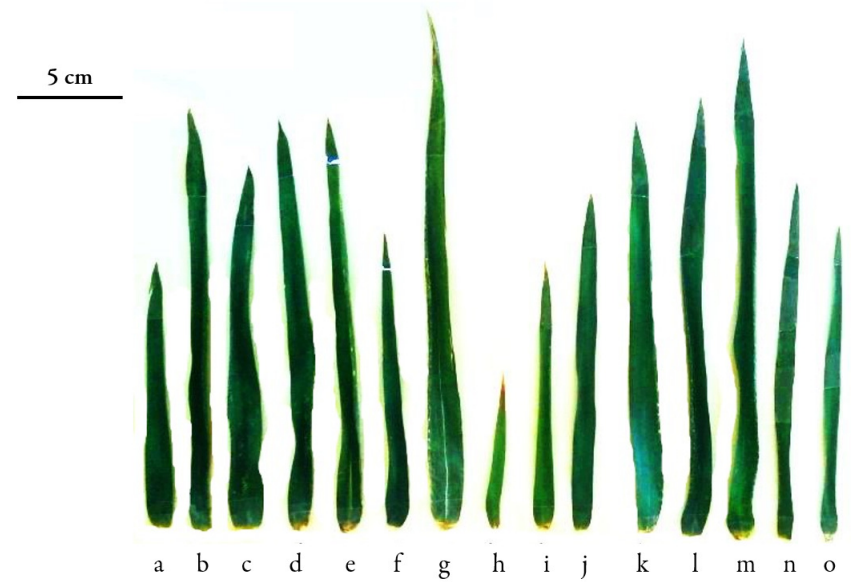

Figure 3. An image indicates the genotypic variations in FLA in rainfed condition

Letters are the representatives of T. aestivum cv. 'Karahan 99' (a), T. durum cv. 'Kunduru 1149' (b), T. aestivum cv. 'Konya 2002' (c), T. durum cv. 'Meram 2002' (d), 'Karakılçık' (e), 'Elytritilops' (f), T. polonicum (g), T. dicoccoides (h), 'Aegilotriticum' (i), T. carthlicum (j), T. turgidum (k), T. compactum (l), T. turanicum (m), 'Agrotriticum' (n), and T. ispahanicum (o). The fully expanded flag leaves were excised from plants. Scale bar is $5 \mathrm{~cm}$. 

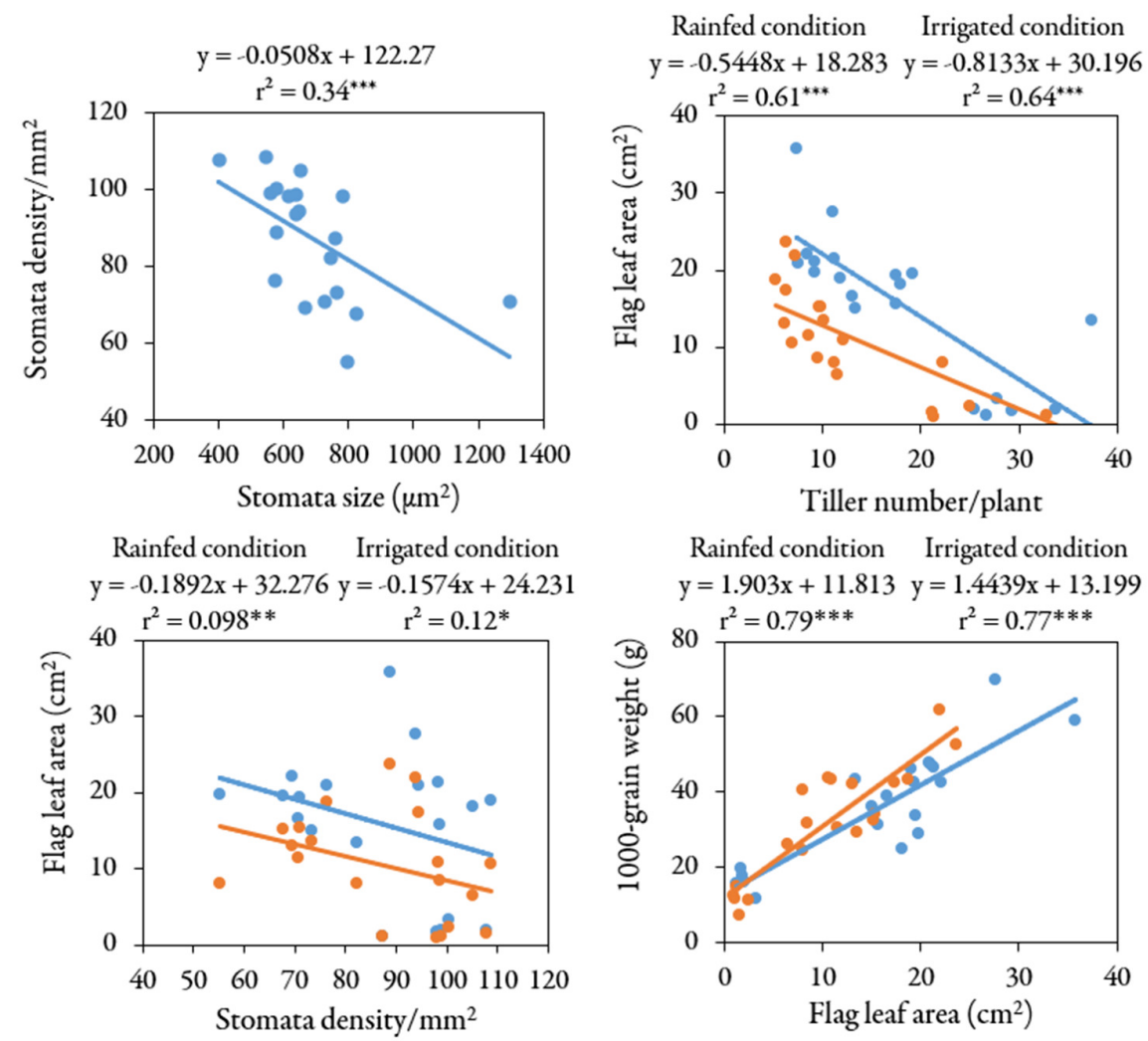

Figure 4. Relationship between/within stomatal and morphological traits of the studied genotypes “*” indicates $\mathrm{P}<0.05$, “**” for $\mathrm{P}<0.01$, and “***” $\mathrm{P}<0.0001$

\section{Discussion}

Stomata size and density vary depending on genetic factors and environmental conditions; the size ranges from 10 and $80 \mu \mathrm{m}$ in length with densities between 5 and $1000 \mathrm{~mm}^{-2}$ (Hetherington and Woodward, 2003). The present study showed that stomata density in two bread wheat cultivars ranged from 69.5 to 70.8 $\mathrm{mm}^{-2}$ (Figure 2). Similarly, the findings resulting from the current study were in agreement with those of Shahinnia et al. (2016) who found that adaxial stomata density in two bread wheat cultivars varied from 61 to $71 \mathrm{~mm}^{-2}$. Mohammady et al. (2007) observed that stomatal traits varied from 44.8 to $51.9 \mu \mathrm{m}$ of stomata length, 24.5 to $31.1 \mu \mathrm{m}$ of stomata width. They also revealed that stomata density differed from 56.2 to $81.5 \mathrm{~mm}^{-2}$ in tetraploid and from 45.6 to $64.5 \mathrm{~mm}^{-2}$ in hexaploid wheat accessions.

The density of stomata on the leaves is a highly heritable characteristic (Hofmann and Dobrenz, 1983; Schoppach et al., 2016). Hexaploid genotypes proved to have lower stomata density compared to tetraploid wheat genotypes. In this study, T. durum cv. 'Kunduru 1149' had a high density of small stomata compared to 'Agrotriticum', 'Aegilotriticum', and T. compactum with low densities of large stomata (Figure 1). These results were similar to the findings reported by Doheny-Adams et al. (2012), who concluded that smaller stomata were usually found in higher densities. Researchers have recently demonstrated pivotal results regarding appropriate stomata traits of plants. Reduced stomatal density has been proved to improve drought tolerance and water-use efficiency in bread wheat, rice, and wood plants (Caine et al., 2019; Dunn et al., 2019; Yin et al., 2020).

In the present study, the hexaploid genotypes with low stomatal density may contribute to the improvement of new drought-tolerant cultivars in environments with reduced water availability. Regarding 
photosynthesis and yield-related stomata traits, leaves with a low density of large stomata have shown lower photosynthetic rates (Drake et al., 2013). It was also suggested that high-yielding rice cultivars possessed a higher stomatal density and slightly shorter stomatal length (Ohsumi et al., 2007). In the present study, tetraploid wheat species had high stomata density, short length, and small size. There are differences in the previous studies about ideal stomata traits in plants, suggesting a high density of small stomata for improved yield and photosynthesis but a low density of large stomata for drought tolerance and water-use efficiency. Hence, further work is needed to elucidate associations between stomatal traits and other physiomorphological, biochemical, and genetic traits under different environmental conditions.

Water deficit has been shown to lead to severe reductions in most morphological traits. It was described, for example, that precipitation was the key indicator for wheat yield evaluation (Tigkas and Tsakiris, 2015). Grain yield can be enhanced by $60 \%$ to $100 \%$ with 200 to $300 \mathrm{~mm}$ of irrigation (Zhang et al., 1999). Meanwhile, in the current study, significant reductions under rainfed conditions compared to the irrigated condition were observed in morphological parameters, such as $9.4 \%$ for plant height, $19.7 \%$ for tillering, and $33.5 \%$ for FLA. The FLA is one of the key determinants underlying wheat grain yield, particularly under drought (Biswal and Kohli, 2013). Ideal FLA is therefore significant for sustaining optimal yield in water deficit conditions (Quarrie et al., 1999). As wheat cultivars that have adapted to irrigated conditions, the FLAs of $T$. aestivum cv. 'Konya 2002' and T. durum cv. 'Meram 2002' were smaller under rainfed conditions and larger under irrigated conditions, whereas T. aestivum cv. 'Karahan 99' and T. durum cv. 'Kunduru 1149' adapted to rainfed condition possessed smaller leaf areas under irrigated conditions. Surprisingly, T. polonicum, T. turanicum, T. durum cv. 'Karakılçı', and T. turgidum maintained larger leaf areas in both conditions compared to other genotypes.

T. ispahanicum, T. carthlicum, and T. dicoccoides had lower FLA values in both growth conditions. Also, 'Aegilotriticum', T. carthlicum, 'Elytritilops', and T. ispahanicum were the most impacted genotypes by water deficit of $48.5 \%$ to $50 \%$ As expected, Aegilops species had inherently lower leaf areas than wheat species and hybrids. Among the Aegilops species, a progenitor of bread wheat, Ae. tauschii, was the least affected species.

This study showed that $T$. ispahanicum and $T$. dicoccoides were the most tillering species in both growth conditions among the studied genotypes. Longnecker et al. (1993) presented similar findings, indicating that tillering was dependent on genotypic and climatic factors. Another previous study reported that the tillering potential of bread wheat was greater than that of durum wheat (Pinthus, 1969). In the present study, there were no clear discriminations in terms of tillering between durum and bread wheat genotypes or tetraploid and hexaploid wheat genotypes. Indeed, T. polonicum, T. turgidum, T. aestivum cv. 'Konya 2002', and T. durum cv. 'Karakılçık' had less tillering capacity than other genotypes in both growth conditions.

Regarding plant height, T. ispahanicum, T. turgidum, T. dicoccoides, 'Elytritilops', and T. durum cv. 'Kunduru 1149' showed higher values in both growth conditions than other genotypes, while T. compactum, 'Aegilotriticum', T. durum cv. 'Karakılçık' (landrace), and modern wheat cultivars had shorter plant heights. Evaluating the spike length and spikelet number, genotypes under rainfed conditions had trends like those seen under irrigated conditions. Genotypes with high values maintained notably greater values in both conditions. The Aegilops species 'Ae. ventricosa' had higher values regarding plant height, spike length, and spikelet number, while 'Ae. geniculata' had lower values.

TGW was shown to be one of the significant indicators determining grain yield (Wu et al., 2018). Previous studies indicated that TGW was significantly and strongly correlated with grain yield (Huang et al., 2020; Öztürk et al., 2020). A close look at the data in Tables 1 and 2 reveals that T. turanicum and T. polonicum had distinguishably higher TGW than the modern wheat cultivars and other studied genotypes in both rainfed and irrigated conditions. Consistent with the findings of the current study, Grausbruger et al. (2005) indicated that T. turanicum, known as Khorasan wheat, often had TGW values of greater than even 60 g. T. turanicum was suggested to be a natural hybrid between T. polonicum (Polish wheat) and durum wheat (Kuckuck, 1959). The caryopsis structure of 'T. turanicum' has similarities with T. polonicum, T. ispahanicum 
(Ispahan emmer), and T. carthlicum (Persian wheat) (Kosina, 1995). Also, T. turanicum was proposed to have wide genetic diversity with multiple agronomic adaptive traits (Lannucci and Codianni, 2019). Regarding $T$. polonicum, TGW can reach up to $80 \mathrm{~g}$ (Wang et al., 2002). In the present study, the TGW of $T$. polonicum in rainfed and irrigated conditions averaged $52.6 \mathrm{~g}$ and $59.1 \mathrm{~g}$, respectively. The TGW of T. turgidum was close to that of modern durum wheat cultivars and higher than modern bread wheat cultivars in both growth conditions. T. ispahanicum possessed TGW values between those of modern bread and durum wheat cultivars in both rainfed and irrigated conditions. Other wheat species and hybrids had lower TGWs than modern wheat cultivars. Morphological parameters may be altered in response to water availability in the soil. It has been reported that wheat needs $450-650 \mathrm{~mm}$ of rainfall annually for optimal development (Zargar and Zargar, 2018). However, this desired rainfall may not occur in a timely manner in the wheat growth stages. Seasonal rainfall irregularity might further exacerbate the adverse effects on wheat growth under rainfed conditions. In the present study, the average TGW was reduced by $11.7 \%$ under rainfed conditions compared to the irrigated condition. T. carthlicum and T. dicoccoides maintained their TGWs under rainfed conditions.

In contrast, T. aestivum cv. 'Karahan 99', 'Elytritilops', and 'Aegilotriticum' were the most affected genotypes in terms of TGW under rainfed conditions compared to the irrigated condition among the wheat species and hybrids (Tables 2 and 3). In Aegilops species, the TGW was influenced most under rainfed conditions, excluding 'Ae. ventricosa'.

\section{Conclusions}

Wheat species, wild relatives, and hybrids have recently attracted researchers' interest based on the genetic diversity in the gene pool. The present study has characterized the variability in stomatal and morphological traits of the studied genotypes. The variations among wheat species, wild relatives, and hybrids were about 2-fold for stomata density and 3.2-fold for stomata size. It was shown that 'Aegilotriticum', 'Agrotriticum', T. compactum, and Ae. tauschii particularly offered differential stomatal characteristics. 'Ae. tauschii had a high density of small stomata, while, conversely, T. compactum, 'Aegilotriticum', and 'Agrotriticum', a hexaploid wheat species and two man-made hybrids, possessed low densities of large stomata. Considering the value of genetic variability for the improvement of wheat in rainfed and irrigated conditions, the best-performing genotypes of $T$. turanicum and $T$. polonicum had considerably high TGW compared to adapted bread wheat cultivars, durum wheat cultivars, and other species. These genotypes with superior characteristics might be evaluated for hybridization studies to transfer valuable genes into wheat.

\section{Acknowledgements}

This research received no specific grant from any funding agency in the public, commercial, or not-forprofit sectors.

\section{Conflict of Interests}

The author declares that there are no conflicts of interest related to this article. The author approved the final manuscript. 


\section{References}

Arzani A, Ashraf M (2017). Cultivated ancient wheats (Triticum spp.): A potential source of health-beneficial food products. Comprehensive Reviews in Food Science and Food Safety 16:477-488. https://doi.org/10.1111/1541-4337.12262

Bibi A, Sadaqat HA, Tahir MHN, Akram HM (2012). Screening of sorghum (Sorghum bicolor var monech) for drought tolerance at seedling stage in polyethyelene glycol. Journal of Animal and Plant Science 22:671- 678.

Biswal AK, Kohli A (2013). Cereal flag leaf adaptations for grain yield under drought: Knowledge status and gaps. Molecular Breeding 31:749-766. https://doi.org/10.1007/s11032-013-9847-7

Buckley TN (2005). The control of stomata by water balance. New Phytologist 168:275-292. https://doi.org/10.1111/j.1469-8137.2005.01543.x

Caine RS, Yin X, Sloan J, Harrison EL, Mohammed U, Fulton T, Coe RA (2019). Rice with reduced stomatal density conserves water and has improved drought tolerance under future climate conditions. New Phytologist 221:371384. https://doi.org/10.1111/nph.15344

Cakmak I, Pfeiffer WH, McClafferty B (2010). Biofortification of durum wheat with zinc and iron. Cereal Chemistry 87:10-20. https://doi.org/10.1094/CCHEM-87-1-0010

Chandra K, Das AK (2000). Correlation and intercorrelation of physiological parameters in rice (Oryza sativa L.) under rainfed transplanted condition. Crop Research 19:251-254.

Cortan D, Vilotic D, Sijacic-Nikolic M, Miljkovic D (2017). Leaf stomatal traits variation within and among black poplar native populations in Serbia. Bosque 38:337-345. https://doi.org/10.4067/S0717-92002017000200011

Doheny-Adams T, Hunt L, Franks PJ, Beerling DJ, Gray JE (2012). Genetic manipulation of stomatal density influences stomatal size, plant growth and tolerance to restricted water supply across a growth carbon dioxide gradient. Philosophical Transactions of the Royal Society B: Biological Sciences 367:547-555. https://doi.org/10.1098/rstb.2011.0272

Drake PL, Froend RH, Franks PJ (2013). Smaller, faster stomata: Scaling of stomatal size, rate of response, and stomatal conductance. Journal of Experimental Botany 64:495-505. https://doi.org/10.1093/jxb/ers347

Dunn J, Hunt L, Afsharinafar M, Meselmani MA, Mitchell A, Howells R, Gray JE (2019). Reduced stomatal density in bread wheat leads to increased water-use efficiency. Journal of Experimental Botany 70:4737-4748. https://doi.org/10.1093/jxb/erz248

Feldman M, Lupton F, Miller T (1995) Wheats. In: Smartt J, Simmonds NW (Eds). Evolution of Crop Plants. 2nd edn. Harlow, UK: Longman Scientific \& Technical, pp 184-192.

Giraldo P, Benavente E, Manzano-Agugliaro F, Gimenez E (2019). Worldwide research trends on wheat and barley: A bibliometric comparative analysis. Agronomy 9:1-18. https://doi.org/10.3390/agronomy9070352

Grausgruber H, Oberforster M, Ghambashidze G, Ruckenbauer P (2005). Yield and agronomic traits of Khorasan wheat (Triticum turanicum Jakubz.). Field Crops Research 91:319-327. https://doi.org/10.1016/j.fcr.2004.08.001

Hetherington AM, Woodward FI (2003). The role of stomata in sensing and driving environmental change. Nature 424:901-908.

Hofmann W, Dobrenz A (1983). Stomate density in sorghum hybrids and parental lines. Forage and Grain: Agriculture report 49-50. Accessed at: http://hdl.handle.net/10150/200440

Huang X, Börner A, Röder M, Ganal M (2002). Assessing genetic diversity of wheat (Triticum aestivum L.) germplasm using microsatellite markers. Theoretical and Applied Genetics 105:699-707. https://doi.org/10.1007/s00122002-0959-4

Huang X, Wang C, Hou J, Du C, Liu S, Kang J, ... Ma D (2020). Coordination of carbon and nitrogen accumulation and translocation of winter wheat plant to improve grain yield and processing quality. Scientific Reports 10(1):1-11. https://doi.org/10.1038/s41598-020-67343-5

Ikanović J, Popović V, Janković S, Živanović L, Rakić S, Dončić D (2014). Khorasan wheat population researching (Triticum turgidum ssp. turanicum (Mckey) in the minimum tillage conditions. Genetika 46:105-115. https://doi.org/10.2298/GENSR1401105I

Kardiman R, Ræbild A (2018). Relationship between stomatal density, size and speed of opening in sumatran rainforest species. Tree Physiology 38:696-705. https://doi.org/10.1093/treephys/tpx149

Kishii M (2019). An update of recent use of Aegilops species in wheat breeding. Frontiers in Plant Science 10:1-19. https://doi.org/10.3389/fpls.2019.00585 
Kosina R (1995). Tetraploids of the genus Triticum in the light of caryopsis structure. Prace Botaniczne, 66, Uniwersytet Wrocławski-Wydawnictwo, Wrocław, Poland

Kuckuck H (1959). Neuere arbeiten zur Entstehung der hexaploiden Kulturweizen. Z. Pflanzenzuchtung 41:205-226.

Lannucci A, Codianni P (2019). Phenotypic parent selection within a Khorasan wheat collection and genetic variation in advanced breeding lines derived by hybridization with durum wheat. Frontiers in Plant Science 10:1-13. https://doi.org/10.3389/fpls.2019.01460

Li D, Long D, Li T, Wu Y, Wang Y, Zeng J, Zhang H (2018). Cytogenetics and stripe rust resistance of wheatThinopyrum elongatum hybrid derivatives. Molecular Cytogenetics 11:1-9. https://doi.org/10.1186/s13039018-0366-4

Limochi K, Eskandari H (2013). Effect of planting date on the performance of flag leaf stomata and grain yield of rice cultivars. International Journal of Agronomy and Plant Production 4:769-773.

Longnecker N, Kirby E, Robson A (1993). Leaf emergence, tiller growth, and apical development of nitrogen-deficient spring wheat. Crop Science 33:154-160. https://doi.org/10.2135/cropsci1993.0011183X003300010028x

Mathre D, Johnston R, Martin J (1985). Sources of resistance to Cephalosporium gramineum in Triticum and Agropyron species. Euphytica 34:419-424. https://doi.org/10.1007/BF00022937

Mohammady S, Khazaei H, Reisi F (2007). The study of stomatal characteristics in iranian wheat wild accessions and land races. Wheat Information Service 103:5-12.

Németh M, Janda T, Horváth E, Páldi E, Szalai G (2002). Exogenous salicylic acid increases polyamine content but may decrease drought tolerance in maize. Plant Science 162: 569-574. https://doi.org/10.1016/S0168-9452(01)00593-3

Ohsumi A, Kanemura T, Homma K, Horie T, Shiraiwa T (2007). Genotypic variation of stomatal conductance in relation to stomatal density and length in rice (Oryza sativa L.). Plant Production Science 10:322-328. https://doi.org/10.1626/pps.10.322

Öztürk İ, Şen A, Kılıç, TH, Şili Ş (2020). Selection of advanced mutant wheat (Triticum aestivum L.) lines based on yield and quality parameters. Turkish Journal of Agricultural and Natural Sciences 7:87-95. https://doi.org/10.30910/Turkjans.680019

Peng J, Sun D, Nevo E (2011). Wild emmer wheat, Triticum dicoccoides, occupies a pivotal position in wheat domestication process. Australian Journal of Crop Science 5:1127.

Peng J, Sun D, Peng Y, Nevo E (2013). Gene discovery in Triticum dicoccoides, the direct progenitor of cultivated wheats. Cereal Research Communications 41:1-22. https://doi.org/10.1556/CRC.2012.0030

Pinthus MJ (1969). Tillering and coronal root formation in some common and durum wheat varieties 1 . Crop Science 9:267-272. https://doi.org/10.2135/cropsci1969.0011183X000900030004X

Quarrie SA, Stojanović J, Pekić S (1999). Improving drought resistance in small-grained cereals: A case study, progress and prospects. Plant Growth Regulation 29:1-21.

Schoppach R, Taylor JD, Majerus E, Claverie E, Baumann U, Suchecki R, Sadok W (2016). High resolution mapping of traits related to whole-plant transpiration under increasing evaporative demand in wheat. Journal of Experimental Botany 67:2847-2860. https://doi.org/10.1093/jxb/erw125

Shahinnia F, Le Roy J, Laborde B, Sznajder B, Kalambettu P, Mahjourimajd S, Fleury D (2016) Genetic association of stomatal traits and yield in wheat grown in low rainfall environments. BMC Plant Biology 16:1-14. https://doi.org/10.1186/s12870-016-0838-9

Suneja Y, Gupta AK, Bains NS (2019). Stress adaptive plasticity: Aegilops tauschii and Triticum dicoccoides as potential donors of drought associated morpho-physiological traits in wheat. Frontiers in Plant Science 10:1-19. https://doi.org/10.3389/fpls.2019.00211

Tigkas D. Tsakiris G (2015). Early estimation of drought impacts on rainfed wheat yield in mediterranean climate. Environmental Processes 2:97-114. https://doi.org/10.1007/s40710-014-0052-4

Ullah S, Bramley H, Daetwyler H, He S, Mahmood T, Thistlethwaite R, Trethowan R (2018). Genetic contribution of emmer wheat (Triticum dicoccon Schrank) to heat tolerance of bread wheat. Frontiers in Plant Science. 9:1-11. https://doi.org/10.3389/fpls.2018.01529

Wang HJ, Huang XQ, Röder MS, Börner A (2002). Genetic mapping of loci determining long glumes in the genus Triticum. Euphytica 123:287-293. https://doi.org/10.1023/a:1014909331902

Wu W, Zhou L, Chen J, Qiu Z, He Y (2018). GainTKW: a measurement system of thousand kernel weight based on the android platform. Agronomy 8:1-15. https://doi.org/10.3390/agronomy8090178 
Yin Q, Tian T, Kou M, Liu P, Wang L, Hao Z, Yue M (2020). The relationships between photosynthesis and stomatal traits on the loess plateau. Global Ecology and Conservation 23:1-8. https://doi.org/10.1016/j.gecco.2020.e01146

Zargar SM, Zargar MY (2018). Abiotic stress-mediated sensing and signaling in plants: An omics perspective. Springer, Singapore. https://doi.org/10.1007/978-981-10-7479-0

Zhang H, Wang X, You M, Liu C (1999). Water-yield relations and water-use efficiency of winter wheat in the north china plain. Irrigation Science 19:37-45. https://doi.org/10.1007/s002710050069

Zwieniecki MA, Haaning KS, Boyce CK, Jensen KH (2016). Stomatal design principles in synthetic and real leaves. Journal of the Royal Society Interface 13:1-6. https://doi.org/10.1098/rsif.2016.0535

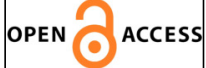

(c) (1)

The journal offers free, immediate, and unrestricted access to peer-reviewed research and scholarly work. Users are allowed to read, download, copy, distribute, print, search, or link to the full texts of the articles, or use them for any other lawful purpose, without asking prior permission from the publisher or the author.

License - Articles published in Notulae Scientia Biologicae are Open-Access, distributed under the terms and conditions of the Creative Commons Attribution (CC BY 4.0) License.

(C) Articles by the authors; SHST, Cluj-Napoca, Romania. The journal allows the author(s) to hold the copyright/to retain publishing rights without restriction. 